\title{
THE HEMODYNAMIC EFFECTS OF HYPOTENSIVE DRUGS IN MAN. II. DIHYDROERGOCORNINE ${ }^{1}$
}

\author{
By EDWARD D. FREIS, ${ }^{2}$ JOSEPH R. STANTON, JULIUS LITTER, ${ }^{3}$ JAMES W. \\ CULBERTSON, MEYER H. HALPERIN, F. CORBIN MOISTER, \\ AND ROBERT W. WILKINS.
}

(From the Evans Memorial, Massachusetts Memorial Hospitals, and the Department of Medicine, Boston University School of Medicine, Boston, Mass.)

(Received for publication, April 9, 1949)

Dale in 1906 recognized the sympatholytic activity of crude extracts of ergot as well as their property of direct stimulation of smooth muscle, including that of the blood vessels (1). Despite their sympatholytic effects their direct vasoconstrictor action prevented significant lowering of arterial pressure.

Later chemical purification of the crude drug resulted in the isolation of five alkaloids: ergotamine (2), ergobasine (3), ergokryptine, ergocornine and ergocristine (4). The basic chemical structure of these compounds was clarified by Jacobs and Craig (5) who demonstrated the presence of lysergic acid in all of the alkaloids (6). By hydrogenating the reducible double bond of the lysergic acid component of four of these alkaloids, Stoll and Hofmann (7) in 1943 produced a new series of compounds, dihydroergotamine, dihydroergocristine, dihydroergocornine (DHO$180)^{5}$ and dihydroergokryptine $(\mathrm{DHK}-135) .^{5}$ Pharmacological studies in animals (8) indicated that these modified compounds have enhanced sympatholytic and adrenolytic properties but little or no direct constrictor action on smooth muscle. In addition, they are hypotensive, this effect being mediated at least in part via the central nervous system (9). In man DHO and DHK in non-toxic doses have sympatholytic and hypotensive prop-

\footnotetext{
1 Supported in part by the Squibb Institute for Medical Research, New Brunswick, New Jersey, Sandoz Pharmaceuticals, New York, New York, and the Dart Foundation, Los Angeles, California. The drugs used were generously supplied by C. Henze, M.D., of Sandoz Pharmaceuticals.

2 Present address, Georgetown University Medical Center, Washington, D. C.

${ }^{3}$ Fellow, Life Insurance Medical Research Fund.

4 On leave of absence from the Mary Hitchcock Memorial Hospital and Dartmouth Medical School, Hanover, New Hampshire.

${ }^{5}$ Hereinafter referred to as DHO and DHK respectively.
}

erties (10-12). Because of their possible value in the treatment of essential hypertension and peripheral vascular disease a further clarification of their hemodynamic effects in man was undertaken.

\section{MATERIALS AND METHODS}

The subjects were patients, mostly hypertensive, admitted to the wards of the Massachusetts Memorial Hospitals. The methods used in this investigation were essentially the same as those described in a previous communication (13). DHO was administered by intravenous injection in a solution of sterile water containing $0.5 \mathrm{mg}$. of active substance per cc. Unless otherwise indicated arterial pressure was measured continuously with a Hamilton manometer (13).

\section{RESULTS}

\section{Sympatholytic Effects}

\section{a. Sympathetic Vasopressor Responses}

Certain vasopressor responses usually abolished or diminished after surgical sympathectomy (14)

TABLE I

Effect of DHO on the responses to the Valsalva maneuver

\begin{tabular}{|c|c|c|c|c|c|c|}
\hline \multirow{3}{*}{ Patient } & \multicolumn{3}{|c|}{ Control } & \multicolumn{3}{|c|}{ After dihydroergocornine } \\
\hline & \multicolumn{2}{|c|}{ Arterial pressure } & \multirow{2}{*}{$\begin{array}{l}\text { Over- } \\
\text { shoot* }\end{array}$} & \multicolumn{2}{|c|}{ Arterial pressure } & \multirow{2}{*}{$\begin{array}{l}\text { Over- } \\
\text { shoot* }\end{array}$} \\
\hline & Basa! & $\begin{array}{c}\text { After } \\
\text { Valsalva }\end{array}$ & & Basal & $\begin{array}{c}\text { After } \\
\text { Valsalva }\end{array}$ & \\
\hline & $\mathrm{mm} . \mathrm{Hg}$ & $m m . H g$ & percent & $\mathrm{mm} . \mathrm{Hg}$ & $\mathrm{mm} . \mathrm{Hg}$ & percent \\
\hline & $230 / 130$ & $256 / 140$ & 10 & $184 / 88$ & $180 / 90$ & 0 \\
\hline & $310 / 150$ & $330 / 170$ & 9 & $238 / 114$ & $216 / 108$ & 0 \\
\hline & $246 / 112$ & $248 / 108$ & 0 & $240 / 110$ & $230 / 110$ & 0 \\
\hline & $200 / 116$ & $260 / 154$ & 31 & $188 / 100$ & $188 / 98$ & 0 \\
\hline & $180 / 85$ & $192 / 88$ & 5 & $160 / 74$ & $150 / 72$ & 0 \\
\hline F.T.† & $220 / 120$ & $220 / 132$ & 4 & $208 / 105$ & $206 / 100$ & 0 \\
\hline C. H. & $186 / 100$ & $264 / 152$ & 45 & $172 / 98$ & $190 / 110$ & 11 \\
\hline P. P. & $280 / 150$ & $360 / 190$ & 28 & $208 / 130$ & $200 / 120$ & 0 \\
\hline & $200 / 128$ & $244 / 140$ & 17 & $150 / 100$ & $130 / 80$ & 0 \\
\hline & $192 / 90$ & $238 / 110$ & 23 & $202 / 92$ & $202 / 92$ & 0 \\
\hline F. & $165 / 100$ & $218 / 12$ & 39 & $142 / 84$ & $120 / 80$ & 0 \\
\hline
\end{tabular}

* Calculated from the "mean" (one-half the sum of the systolic and diastolic) pressure.

$\dagger$ Following bilateral lumbodorsal splanchnicectomy two years (J. D.) and two weeks (F. T.) respectively. 


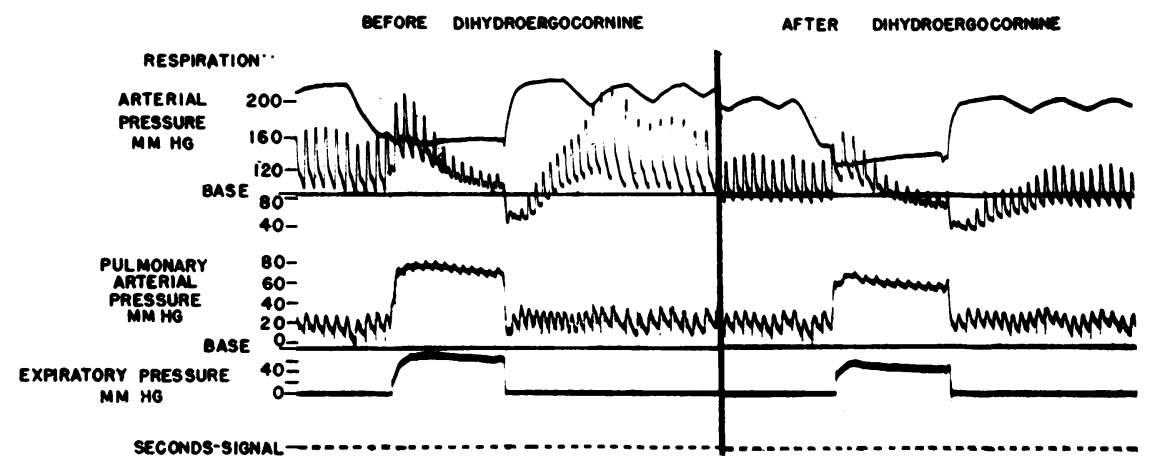

Fig. 1. Optical Records of the Systemic (Femoral) and Pulmonary Arterial Pressure during the Valsalva Maneuver Before and After the Intravenous Administration of 0.4 Mg. of Dihydroergocornine in Patient F. S.

In the control period there was a marked overshoot of the systemic, but not the pulmonary arterial pressure following the release of the expiratory effort. After dihydroergocornine the overshoot of systemic pressure was completely abolished. In the respiratory tracing inspiration is down.

were completely blocked or definitely inhibited after DHO. These included :

\section{The Valsalva Overshoot}

After the intravenous administration of $\mathrm{DHO}$ there was complete abolition of the pressor response to the Valsalva maneuver in ten, and marked inhibition in one of 11 patients tested (Table I, Figure 1). The suppression of this vasopressor response developed gradually so that complete abolition did not occur until ten to 20 minutes after the intravenous injection of the drug.
Maintenance of Arterial Pressure During Orthostasis and the Overshoot on Tiltback

After DHO three of four patients with uncomplicated essential hypertension manifested varying degrees of orthostatic hypotension (Table II) while the fourth developed collapse two and onehalf minutes after being tilted to an angle of $75^{\circ}$. Two other hypertensive patients who had undergone lumbodorsal splanchnicectomy (J. D. and F. T., Table II) and one normotensive patient with hyperthyroidism (V.C.) had greater postural hypotension after than before the drug. In all

TABLE II

The effect of DHO on the responses to the upright posture and quick tiltback

\begin{tabular}{|c|c|c|c|c|c|c|c|c|}
\hline \multirow{3}{*}{ Patient } & \multicolumn{4}{|c|}{ Control } & \multicolumn{4}{|c|}{ After DHO } \\
\hline & \multirow{2}{*}{$\begin{array}{l}\text { Basal arterial } \\
\text { pressure }\end{array}$} & \multicolumn{2}{|c|}{$\begin{array}{l}\text { After four minutes in } \\
\text { upright position }\end{array}$} & \multirow{2}{*}{$\begin{array}{l}\text { Tiltback over- } \\
\text { shoot mean } \\
\text { arterial } \\
\text { pressure }\end{array}$} & \multirow{2}{*}{$\begin{array}{c}\text { Basal arterial } \\
\text { pressure }\end{array}$} & \multicolumn{2}{|c|}{$\begin{array}{l}\text { After four minutes in } \\
\text { upright position }\end{array}$} & \multirow{2}{*}{$\begin{array}{c}\text { Tiltback over } \\
\text { shoot mean } \\
\text { arterial } \\
\text { pressure }\end{array}$} \\
\hline & & $\begin{array}{l}\text { Arterial } \\
\text { pressure }\end{array}$ & $\begin{array}{l}\text { Increase in } \\
\text { heart rate }\end{array}$ & & & Arterial pressure & $\begin{array}{l}\text { Increase in } \\
\text { heart rate }\end{array}$ & \\
\hline $\begin{array}{l}\text { V. C.* } \\
\text { J. D. }{ }^{*} \\
\text { M. T. } \\
\text { F. T. }{ }^{\dagger} \\
\text { E. M. }\end{array}$ & $\begin{array}{l}\mathrm{mm} . \mathrm{Hg} \\
130 / 68 \\
240 / 110 \\
180 / 85 \\
220 / 122 \\
203 / 108\end{array}$ & $\begin{array}{l}m m . H g \\
126 / 88 \\
208 / 112 \\
185 / 84 \\
175 / 115 \\
194 / 110\end{array}$ & $\begin{array}{c}\text { per cent } \\
18 \\
8 \\
5 \\
44 \\
12\end{array}$ & $\begin{array}{c}\text { per cent } \\
24 \\
1 \\
5 \\
0 \\
13\end{array}$ & $\begin{array}{l}\mathrm{mm} . \mathrm{Hg} \\
138 / 68 \\
210 / 100 \\
155 / 78 \\
210 / 107 \\
175 / 100\end{array}$ & $\begin{array}{c}\mathrm{mm.Hg} \\
119 / 55 \\
162 / 100 \\
106 / 82 \\
144 / 80 \\
107 / 54 \\
\text { at two and } \\
\text { one-half } \\
\text { minutes } \\
170 / 92\end{array}$ & $\begin{array}{c}\text { percent } \\
11 \\
6 \\
0 \\
28 \\
\text { Bradycardia } \\
\text { (collapse) }\end{array}$ & $\begin{array}{c}\text { per cent } \\
0 \\
0 \\
0 \\
0 \\
0\end{array}$ \\
\hline
\end{tabular}

* Hyperthyroidism-normotensive.

$\dagger$ Post-sympathectomy. 
TABLE III

Effect of DHO on the responses to the cold pressor test.

\begin{tabular}{|c|c|c|c|c|c|c|}
\hline \multirow{3}{*}{ Patient } & \multicolumn{3}{|c|}{ Control } & \multicolumn{3}{|c|}{ After dihydroergocornine } \\
\hline & \multicolumn{3}{|c|}{ Arterial pressure } & \multicolumn{3}{|c|}{ Arterial pressure } \\
\hline & Basal & $\begin{array}{l}\text { Peak } \\
\text { response } \\
\text { to ice }\end{array}$ & $\begin{array}{c}\text { In- } \\
\text { crease* }\end{array}$ & Basal & $\begin{array}{l}\text { Peak } \\
\text { response } \\
\text { to ice }\end{array}$ & $\begin{array}{c}\text { In- } \\
\text { crease* }\end{array}$ \\
\hline & $m m . \mathrm{Hg}$ & $\mathrm{mm} . \mathrm{Hg}$ & $\begin{array}{l}\text { per } \\
\text { cent }\end{array}$ & $\mathrm{mm} . \mathrm{Hg}$ & $m m . H g$ & $\begin{array}{l}\text { per } \\
\text { cent }\end{array}$ \\
\hline $\begin{array}{l}\text { K. M. } \\
\text { J. D.† } \\
\text { M. T. } \\
\text { J. S. } \\
\text { C. H. } \\
\text { M. M. } \\
\text { I. F. } \\
\text { C. M. } \\
\text { N. McK. }\end{array}$ & $\begin{array}{c}218 / 140 \\
230 / 106 \\
160 / 80 \\
186 / 96 \\
170 / 90 \\
93 / 74 \\
113 / 81 \\
170 / 109 \\
199 / 129\end{array}$ & $\begin{array}{l}240 / 156 \\
283 / 126 \\
195 / 90 \\
214 / 117 \\
194 / 104 \\
132 / 94 \\
124 / 94 \\
202 / 122 \\
228 / 142\end{array}$ & $\begin{array}{r}10 \\
22 \\
19 \\
18 \\
15 \\
35 \\
12 \\
16 \\
9\end{array}$ & $\begin{array}{l}160 / 82 \\
234 / 108 \\
150 / 76 \\
178 / 91 \\
150 / 82 \\
101 / 79 \\
105 / 79 \\
155 / 99 \\
195 / 127\end{array}$ & $\begin{array}{l}170 / 90 \\
230 / 115 \\
168 / 80 \\
188 / 95 \\
160 / 87 \\
120 / 94 \\
112 / 90 \\
166 / 116 \\
206 / 138\end{array}$ & $\begin{array}{r}7 \\
1 \\
10 \\
5 \\
7 \\
19 \\
9 \\
10 \\
7\end{array}$ \\
\hline
\end{tabular}

*Calculated from the "mean" (one-half the sum of systolic and diastolic) pressure.

$\dagger$ Two years following bilateral lumbodorsal splanchnicectomy.

cases the vasopressor overshoot which normally occurs on tilting quickly from the erect to the supine position was completely abolished by the drug.

\section{The Cold Pressor Response}

This response, which is inhibited after dibenamine (15), tetraethylammonium chloride (16), continuous caudal (17) and high spinal anesthesia (18), was partially inhibited in all nine patients tested after as compared with before the administration of DHO (Table III).

\section{b. Digital Thermometric and Plethysmographic Responses}

Of six patients examined in a room maintained at $72^{\circ} \mathrm{F}$ only one exhibited a significant rise in the temperature of the fingers and toes following the drug. On decreasing the room temperature to $68^{\circ} \mathrm{F}$ the temperature of the digits in this subject fell precipitously to below pre-drug levels. By contrast in three cases examined at a room temperature of $78^{\circ} \mathrm{F}$ after a control period of more than one hour the intravenous injection of $\mathrm{DHO}$ was followed by marked elevations of skin temperature in the digits. Thus, vasodilatation as indicated by rises in skin temperature following DHO appeared to be weak and to depend partly on the temperature of the environment.
Digit plethysmograms were recorded in four patients before and after DHO 180 . The pulse volume in both fingers and toes increased after the drug in all four cases, and in three increased markedly. Re-examination of one of these patients seven hours after the drug had been administered revealed a persistence of the marked increase in pulse volume (Figure 2). Reflex vasoconstrictions to "noxious" stimuli (ice, deep breath) were abolished in one case, inhibited in one (Figure 2), and unaffected in one case. In the remaining subject reflex vasoconstrictions after ice, but not after deep breath, were abolished. The normal phasic variations in digital volume were not significantly inhibited in any one of these subjects.

\section{Blood Flow' Through Various Arcas}

\section{Blood Flow Through the Forearm and Leg}

The changes in blood flow in the limbs with the circulation to the hand and foot excluded (13) were determined before and after the intravenous administration of $\mathrm{DHO}$ in 11 hypertensive patients and three normotensive subjects. In the six patients who exhibited the greatest reduction in arterial pressure (Table IV), the mean decrease in arterial pressure was 10.9 per cent while the mean increase in blood flow was 21.3 per cent in the forearm and 10.8 per cent in the leg. Thus, peripheral resistance usually was definitely decreased in this group.

However, the average changes in the hypertensive group as à whole were not as marked. The mean blood flow in the forearm increased slightly ( 8.3 per cent), from $3.44 \mathrm{cc}$. per $100 \mathrm{cc}$. limb volume (range 1.68 to $6.51 \mathrm{cc}$.) to $3.66 \mathrm{cc}$ (range 1.43 to $7.80 \mathrm{cc}$. [Table V]). In the leg the mean blood flow also increased 5.4 per cent, from 3.31 per $100 \mathrm{cc}$ limb volume (range 1.94 to 5.61 ) to $3.44 \mathrm{cc}$. (range 1.66 to $6.20 \mathrm{cc}$.). The mean arterial pressure exhibited an average decrease of 8.7 per cent (range 1.3 to 19.4 per cent).

Although in most instances peripheral resistance decreased there were certain exceptions. In some cases, the blood flow decreased as the arterial pressure fell. Frequently, the maximum increase in blood flow in the extremities occurred before or after the arterial pressure reached its minimum, and blood flow changes in the forearm and leg often did not occur synchronously or even in the 
FREIS, STANTON, LITTER, CULBERTSON, HALPERIN, MOISTER, AND WILKINS

TABLE IV

Delailed data on effects of dihydroergocornine on the arterial pressure and the blood flow in forearm and leg of the patients who exhibited significant reductions in arteria! pressure

\begin{tabular}{|c|c|c|c|c|c|c|c|c|c|c|c|c|c|c|}
\hline \multirow{3}{*}{$\begin{array}{c}\text { Case } \\
\text { no. }\end{array}$} & \multirow{3}{*}{ Patient and diagnosis } & \multirow{3}{*}{ Sex } & \multirow{3}{*}{ Age } & \multirow{3}{*}{ Dose } & \multicolumn{3}{|c|}{ Control } & \multicolumn{7}{|c|}{ After DHO-180 } \\
\hline & & & & & \multirow{2}{*}{$\begin{array}{l}\text { Arterial } \\
\text { pressure }\end{array}$} & \multicolumn{2}{|c|}{$\begin{array}{l}\text { Blood flow } \\
\text { cc./100 cc. } \\
\text { limb volume }\end{array}$} & \multirow{2}{*}{$\begin{array}{l}\text { Time } \\
\text { after } \\
\text { drug }\end{array}$} & \multirow{2}{*}{$\begin{array}{l}\text { Arterial } \\
\text { pressure }\end{array}$} & \multirow{2}{*}{$\begin{array}{c}\text { Maximum } \\
\text { per cent } \\
\text { change in } \\
\text { mean arte- } \\
\text { rial pressure }\end{array}$} & \multicolumn{2}{|c|}{$\begin{array}{l}\text { Blood flow } \\
\text { cc. } / 100 \mathrm{cc} \text {. } \\
\text { limb volume }\end{array}$} & \multicolumn{2}{|c|}{$\begin{array}{l}\text { Per cent change } \\
\text { in blood flow }\end{array}$} \\
\hline & & & & & & Arm & Leg & & & & Arm & Leg & Arm & Leg \\
\hline 1 & $\begin{array}{c}\text { L. K. } \\
\text { Essential } \\
\text { hypertension }\end{array}$ & $\mathrm{F}$ & 37 & $\begin{array}{l}m g . \\
0.3\end{array}$ & $\mid \begin{array}{c}m m . H g \\
176 / 150 \\
187 / 154^{*}\end{array}$ & $\begin{array}{l}2.03 \\
3.31^{*}\end{array}$ & - & \begin{tabular}{|c|} 
minutes \\
7 \\
35 \\
90
\end{tabular} & \begin{tabular}{|c|}
$\mathrm{mm} . \mathrm{Hg}$ \\
$167 / 132$ \\
$163 / 112$ \\
$166 / 119$
\end{tabular} & $-\overline{19.4}$ & $\begin{array}{l}3.27 \\
3.08 \\
3.67\end{array}$ & - & $\begin{array}{lr}- & 1.2 \\
- & 7.0 \\
+ & 10.9\end{array}$ & - \\
\hline 2 & $\begin{array}{c}\text { A. D'I. } \\
\text { Essential } \\
\text { hypertension } \\
\text { malignant phase }\end{array}$ & M & 58 & 0.4 & $\begin{array}{l}239 / 137 \\
238 / 129 \\
239 / 129 *\end{array}$ & $\begin{array}{l}4.20 \\
4.62 \\
4.78^{*}\end{array}$ & $\begin{array}{l}4.18 \\
4.58 \\
4.61 *\end{array}$ & $\begin{array}{r}8 \\
11 \\
-\end{array}$ & $\begin{array}{l}211 / 118 \\
213 / 115 \\
-\end{array}$ & $-\overline{10.9}$ & $\begin{array}{l}5.32 \\
5.47 \\
-\end{array}$ & $\begin{array}{c}4.97 \\
5.11 \\
-\end{array}$ & $\begin{array}{l}+11.3 \\
+\quad 14.4 \\
-\end{array}$ & $\begin{array}{l}+7.8 \\
+10.9 \\
-\end{array}$ \\
\hline 3 & $\begin{array}{c}\text { C. M. } \\
\text { Essential } \\
\text { hypertension }\end{array}$ & $\mathrm{F}$ & 55 & $\begin{array}{c}0.25 \\
\\
0.25 \text { at } \\
34 \text { min- } \\
\text { utes }\end{array}$ & $\begin{array}{l}175 / 110 \\
169 / 102 \\
170 / 109 *\end{array}$ & $\begin{array}{l}1.89 \\
1.82 \\
1.68^{*}\end{array}$ & $\begin{array}{l}2.50 \\
2.46 \\
2.46^{*}\end{array}$ & $\begin{array}{r}6 \\
17 \\
30 \\
53 \\
63 \\
74\end{array}$ & $\begin{array}{l}163 / 99 \\
157 / 101 \\
155 / 95 \\
155 / 98 \\
152 / 96 \\
155 / 99\end{array}$ & $\begin{array}{c}-\bar{z} \\
-\overline{10.4} \\
-\overline{11.1} \\
-\end{array}$ & $\begin{array}{l}1.51 \\
1.43 \\
1.52 \\
2.02 \\
1.97 \\
1.67\end{array}$ & $\begin{array}{l}2.20 \\
2.22 \\
2.18 \\
2.76 \\
2.94 \\
2.52\end{array}$ & $\begin{array}{rr}- & 10.1 \\
- & 14.9 \\
- & 9.5 \\
+ & 20.3 \\
+ & 17.3 \\
- & 0.6\end{array}$ & $\begin{array}{l}-10.6 \\
-9.8 \\
-11.4 \\
+12.2 \\
+19.5 \\
+\quad 2.4\end{array}$ \\
\hline 4 & $\begin{array}{c}\text { L. LeL. } \\
\text { Essential } \\
\text { hypertension }\end{array}$ & M & 48 & 0.3 & $\begin{array}{l}160 / 94 \\
147 / 96^{*}\end{array}$ & $\begin{array}{l}2.39 \\
2.24^{*}\end{array}$ & $\begin{array}{l}2.41 \\
2.28^{*}\end{array}$ & $\begin{array}{r}7 \\
12 \\
26 \\
44\end{array}$ & $\begin{array}{l}141 / 90 \\
139 / 88 \\
135 / 87 \\
141 / 91\end{array}$ & $\begin{array}{l}-\overline{-} \\
-\overline{8} .6\end{array}$ & $\begin{array}{l}2.39 \\
2.38 \\
2.12 \\
2.28\end{array}$ & $\begin{array}{l}1.88 \\
1.66 \\
1.70 \\
1.74\end{array}$ & $\begin{array}{ll}+ & 6.7 \\
+ & 6.3 \\
- & 5.4 \\
+ & 1.8\end{array}$ & $\begin{array}{l}-17.5 \\
-27.2 \\
-25.4 \\
-23.7\end{array}$ \\
\hline 5 & $\begin{array}{c}\text { L. LeC. } \\
\text { Essential } \\
\text { hypertension }\end{array}$ & M & 48 & $\begin{array}{c}0.3 \\
0.15 \text { at } \\
32 \text { min- } \\
\text { utes }\end{array}$ & $\mid \begin{array}{l}243 / 129 \\
250 / 129 \\
252 / 135^{*}\end{array}$ & $\begin{array}{l}2.53 \\
2.03 \\
2.11^{*}\end{array}$ & $\begin{array}{l}2.76 \\
2.27 \\
2.41^{*}\end{array}$ & $\begin{array}{r}7 \\
12 \\
29 \\
39 \\
44 \\
60\end{array}$ & $\begin{array}{l}227 / 128 \\
238 / 133 \\
228 / 127 \\
231 / 127 \\
229 / 129 \\
235 / 135\end{array}$ & $\begin{array}{c}-8.3 \\
- \\
-7.5 \\
-7.5 \\
-\end{array}$ & $\begin{array}{l}2.86 \\
3.58 \\
3.86 \\
4.38 \\
4.67 \\
5.01\end{array}$ & $\begin{array}{l}3.35 \\
3.96 \\
3.85 \\
4.38 \\
4.48 \\
4.68\end{array}$ & $\begin{array}{r}+35.6 \\
+\quad 69.7 \\
+83.0 \\
+107.7 \\
+121.2 \\
+138.0 \\
\end{array}$ & $\begin{array}{r}+39.0 \\
+64.3 \\
+59.8 \\
+81.8 \\
+85.9 \\
+94.2 \\
\end{array}$ \\
\hline 6 & $\underset{\substack{\text { Essential } \\
\text { hypertension }}}{\text { R. }}$ & $\mathrm{F}$ & 39 & 0.3 & $\begin{array}{l}168 / 105 \\
169 / 101 *\end{array}$ & $\begin{array}{l}2.33 \\
2.31 \\
2.21^{*}\end{array}$ & $\begin{array}{l}1.86 \\
1.99 \\
1.94^{*}\end{array}$ & $\begin{array}{r}5 \\
25 \\
47 \\
62\end{array}$ & $\begin{array}{l}175 / 105 \\
153 / 97 \\
153 / 97 \\
155 / 97\end{array}$ & $\begin{array}{l}-7.4 \\
-7.4 \\
-\end{array}$ & $\begin{array}{l}1.86 \\
2.19 \\
2.55 \\
3.09\end{array}$ & $\begin{array}{l}1.89 \\
1.90 \\
2.16 \\
2.28\end{array}$ & $\begin{array}{rr}- & 15.8 \\
- & 0.9 \\
+ & 15.4 \\
+ & 39.8\end{array}$ & $\begin{array}{l}-2.6 \\
-2.1 \\
+11.3 \\
+17.5\end{array}$ \\
\hline
\end{tabular}

* Last control determinations. Post-drug per cent changes in mean arterial pressure and blood flow are calculated from these data. Values for maximum per cent change in mean arterial pressure correspond with other post-drug data on same line.

same direction. Similar inconstant changes in blood flow were observed in three normotensive subjects (Cases 12-14, Table V).

\section{Estimated Hepatic-Portal Blood Flow}

The effect of $\mathrm{DHO}$ on the estimated rate of hepatic-portal blood flow was studied in four hypertensive patients (Table VI), all of whom reacted with substantial reductions in arterial pressure. In the first patient (F. A.) blood flow was reduced in each of the first three measurements after $\mathrm{DHO}$, but in the fourth had returned to the control range despite a continued moderate reduction of pressure. The second patient (J. C.,
Table VI, Figure 3), five minutes after receiving $\mathrm{DHO}$, had a blood flow rate still within control range in the presence of a considerable reduction in arterial pressure, but in all five subsequent observations during the ensuing 88 minutes had a proportionately greater reduction in flow than in pressure. The third patient (C. B.) resembled the first, while the fourth (C. R.) was similar to the second, except that at 24 and 36 minutes after $\mathrm{DHO}$ was given he developed collapse with a blood pressure of $86 / 50 \mathrm{~mm}$. $\mathrm{Hg}$. There was a spontaneous recovery and the pressure became stabilized at approximately $104 / 60 \mathrm{~mm}$. $\mathrm{Hg}$. When the effects of $\mathrm{DHO}$ had been observed for 
more than an hour in this patient, an intramuscular injection of ephedrine sulfate ( $33 \mathrm{mg}$.) was given and was followed by an increase in both hepaticportal blood flow and arterial pressure (Table VI).

All four experiments demonstrated striking re- ductions in hepatic-portal blood flow following injection of $\mathrm{DHO}$, the maximal fall from the average control level being $37,73,61$, and 58 per cent, respectively. These were greater than the corresponding reductions in arterial pressure of $23,20,33$,
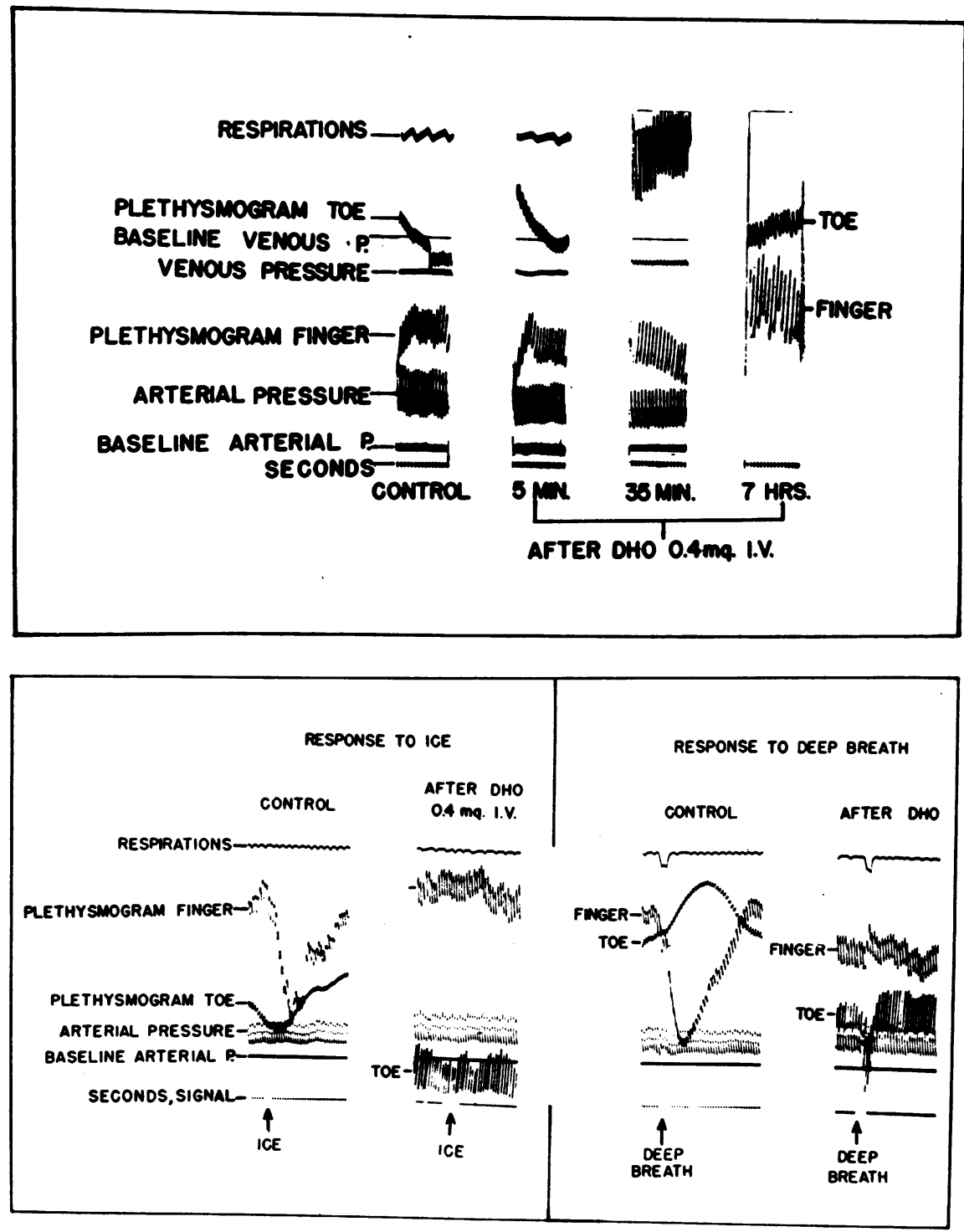

FIG. 2

Optical records, above, of the changes in the antecubital venous pressure, brachial arterial pressure and finger and toe plethysmograms following the intravenous administration of $0.4 \mathrm{mg}$ of dihydroergocornine in patient A. A. Following the drug a marked increase in the pulse volume of both finger and toe occurred which was still evident after seven hours. The antecubital venous pressure rose and exhibited an increase in arterial pulsations.

The lower tracing also illustrates the increase in pulse volume of the finger and toe plethysmograms and, in addition, shows the inhibition of the reflex responses to a deep breath and the application of ice to the forehead after $0.4 \mathrm{mg}$. of dihydroergocornine in patient E. K. 
and 29. per cent, respectively. Vascular resistance appeared to be unchanged or increased in the presence of a reduced level of arterial pressure in 16 of 19 observations on the effects of this drug, suggesting that "splanchnic" arteriolar dilatation was not an important factor in the hypotensive response.

\section{Renal Blood Flow}

Of the five hypertensive patients examined two exhibited marked reductions in arterial pressure following DHO (F. A. and K. M., Table VII, Figure 4) and three had moderate reductions. In patient $\mathrm{F}$. A. the arterial pressure fell suddenly from $300 / 150$ to $167 / 90$ over a period of three and one-half minutes after the drug. This sudden hypotensive response was accompanied by a marked fall in renal plasma flow from 300 to $90 \mathrm{cc}$. per minute. However, the renal plasma flow returned to control values during the next ten minutes despite only partial return of the arterial pressure. The changes in renal plasma flow followed a similar pattern in patient K. M., while in the remaining three patients, in whom arterial pressure changes were not marked, the renal plasma flow decreased slightly, remaining somewhat depressed in two and increasing in the other after 25 minutes to approximately control levels. Thus, in all five cases renal plasma flow decreased initially; it remained slightly depressed in two and returned to approximately control values in three.

It is of interest that in subject F. A. both renal and hepatic-portal blood flow rates were estimated

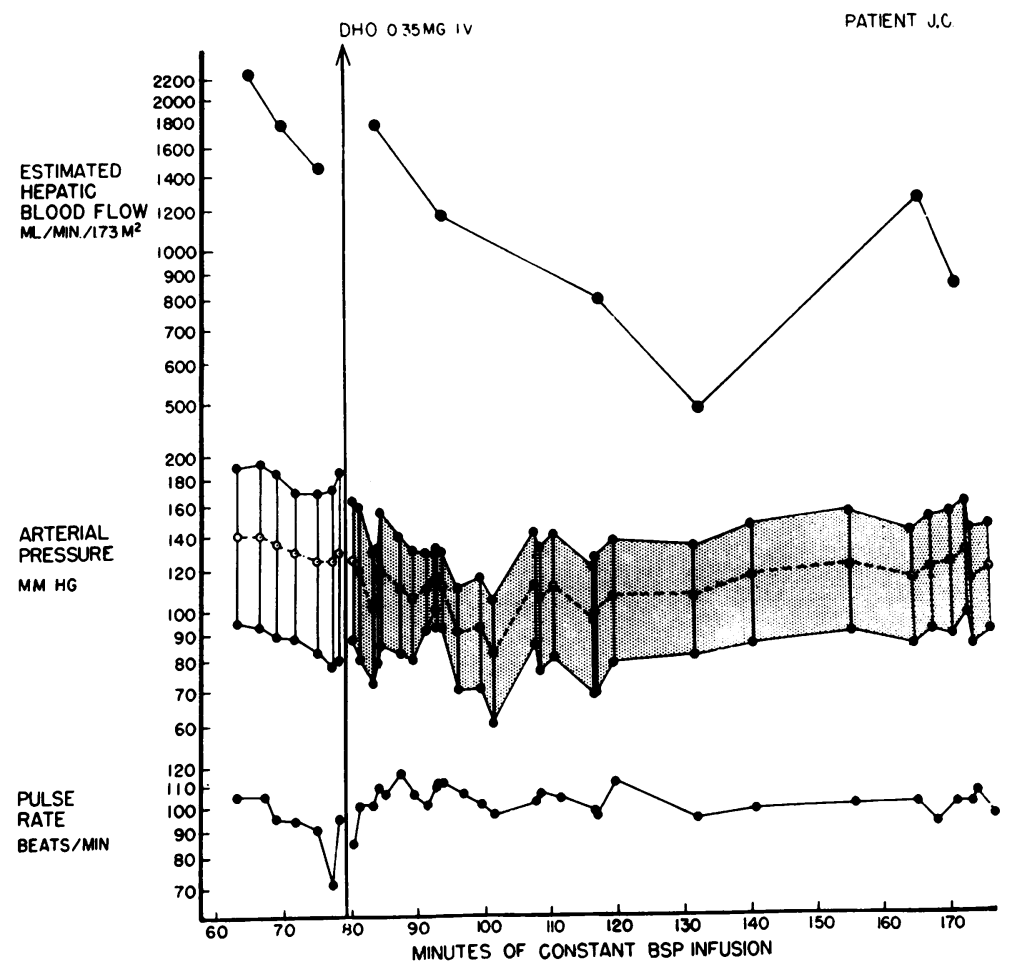

Fig. 3. Chart of the Changes in Estimated Hepatic-Portal Blood Flow, Arterial Pressure and Heart Rate (Hamilton) Before and After the Intravenous Administration of 0.35 mg. of DHO in Patient J. C.

Five minutes after $\mathrm{DHO}$ during a sudden reduction in arterial pressure the hepatic-portal flow was maintained indicating a decrease in peripheral resistance. Following this initial period, however, the hepatic blood flow fell, gradually returning toward control values 85 minutes after the drug was administered. Calculated "crude peripheral resistance" remained increased following the initial period. 
TABLE $V$

Summary of effects of dihydroergocornine on the arterial pressure and the blood flow in forearm and leg

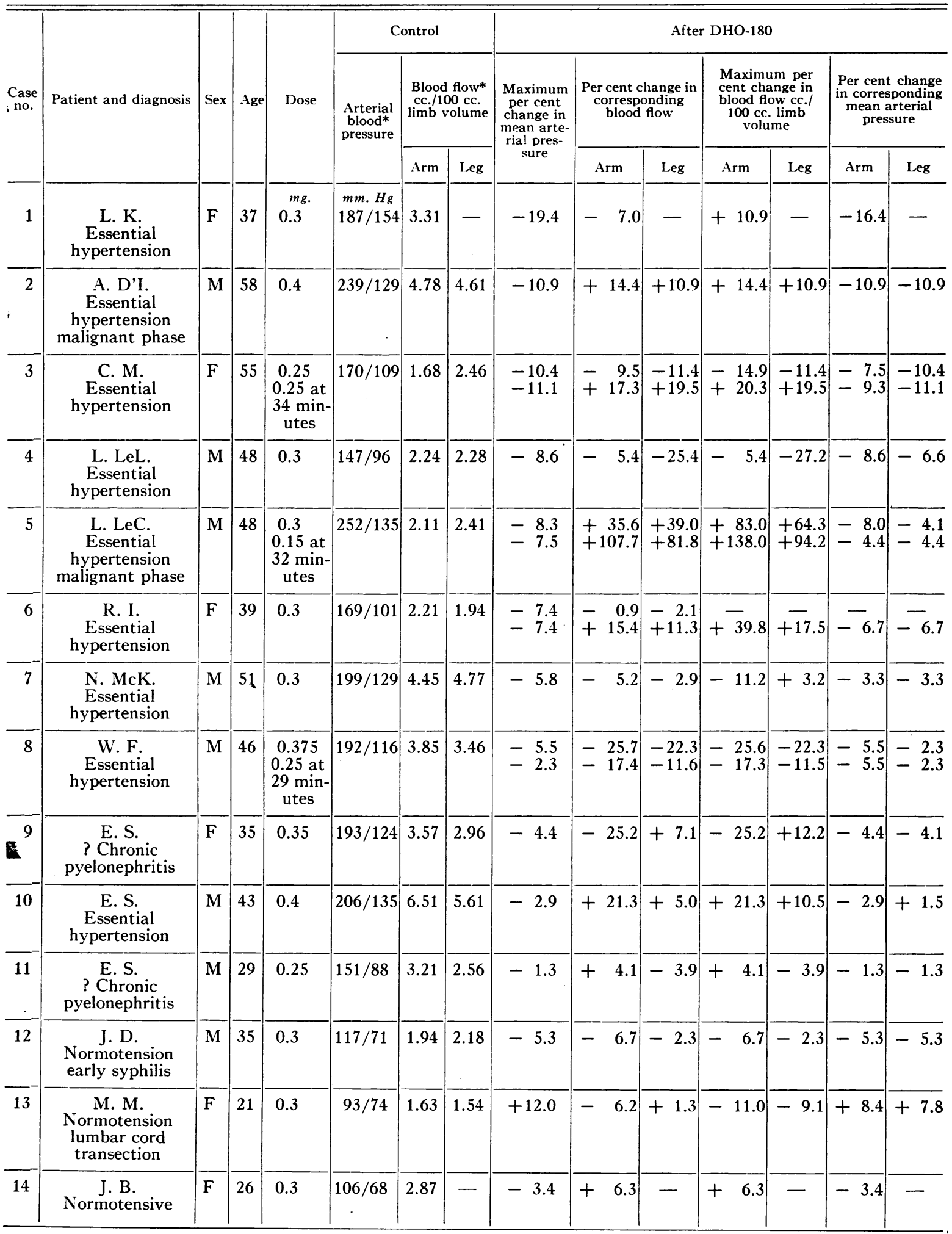

* Last control determinations. All post-drug per cent changes in mean arterial pressure and blood flow are calculated from these data. In cases 3,5 and 8 , the second line of post-drug values corresponds to the second dose of DHO180. 
TABLE VI

Effects of dihydroergocornine on estimated hepatic-portal blood flow

\begin{tabular}{|c|c|c|c|c|c|c|c|c|c|}
\hline \multirow[b]{2}{*}{ Patient } & \multirow[b]{2}{*}{ Sex } & \multirow[b]{2}{*}{ Age } & \multicolumn{2}{|c|}{ Control period } & \multicolumn{5}{|c|}{ After intravenous dihydroergocornine } \\
\hline & & & $\begin{array}{l}\text { Arterial blood } \\
\text { pressure }\end{array}$ & E. H. B. F. & Dose & $\begin{array}{c}\text { Time after } \\
\text { drug adminis- } \\
\text { tration }\end{array}$ & $\begin{array}{l}\text { Arterial blood } \\
\text { pressure }\end{array}$ & E. H. B. F. & $\begin{array}{l}\text { Change in } \\
\text { crude resist- } \\
\text { ance* }\end{array}$ \\
\hline F. A. & M & 59 & $\begin{array}{c}m m . H g \\
307 / 157 \\
305 / 154\end{array}$ & $\begin{array}{c}\text { ml. per min. per } \\
1.73 \text { sq.m. } \\
1457 \\
1601\end{array}$ & $\begin{array}{l}m g . \\
0.40\end{array}$ & $\begin{array}{c}\text { minutes } \\
3 \\
12 \\
23 \\
33\end{array}$ & $\begin{array}{c}\mathrm{mm} . \mathrm{Hg} \\
277 / 140 \\
235 / 120 \\
234 / 115 \\
226 / 116\end{array}$ & $\begin{array}{c}\text { ml. per min. per } \\
\text { 1.73 sq.m. } \\
1319 \\
965 \\
1202 \\
1501\end{array}$ & $\begin{array}{r}0 \\
+ \\
0 \\
-\end{array}$ \\
\hline J. C. & M & 58 & $\begin{array}{l}185 / 95 \\
180 / 89 \\
168 / 83\end{array}$ & $\begin{array}{l}2240 \\
1765 \\
1445\end{array}$ & 0.35 & $\begin{array}{r}5 \\
14 \\
38 \\
53 \\
87 \\
93\end{array}$ & $\begin{array}{l}132 / 79 \\
132 / 92 \\
126 / 69 \\
132 / 81 \\
142 / 85 \\
154 / 89\end{array}$ & $\begin{array}{r}1777 \\
1172 \\
808 \\
483 \\
1247 \\
844\end{array}$ & $\begin{array}{l}- \\
+ \\
+ \\
+ \\
+ \\
+\end{array}$ \\
\hline C. B. & $\mathrm{F}$ & 53 & $\begin{array}{l}260 / 158 \\
267 / 162\end{array}$ & $\begin{array}{r}1162 \\
953\end{array}$ & 0.30 & $\begin{array}{r}5 \\
10 \\
30 \\
42\end{array}$ & $\begin{array}{l}205 / 124 \\
172 / 111 \\
164 / 108 \\
160 / 100\end{array}$ & $\begin{array}{l}806 \\
418 \\
594 \\
471\end{array}$ & $\begin{array}{l}0 \\
+ \\
+ \\
+\end{array}$ \\
\hline C. R. & M & 50 & $\begin{array}{l}176 / 100 \\
176 / 100 \\
170 / 101\end{array}$ & $\begin{array}{r}1163 \\
910 \\
874\end{array}$ & $\dagger$ & $\begin{array}{r}3 \\
7 \\
20 \\
35 \\
60 \\
72 \\
85\end{array}$ & $\begin{array}{c}154 / 85 \\
142 / 85 \\
118 / 75 \\
93 / 53 \\
108 / 62 \\
- \\
135 / 81 \\
152 / 88\end{array}$ & $\begin{array}{r}860 \\
758 \\
441 \\
766 \\
690 \\
\overline{726} \\
1070\end{array}$ & $\begin{array}{l}0 \\
0 \\
+ \\
0 \\
- \\
0 \\
-\end{array}$ \\
\hline
\end{tabular}

* Change is recorded as positive or negative values above or below the range of resistance values observed during control period. Variation within control range $=0$ change. Crude resistance $=$ average arterial pressure $\div$ E.H.B.F. $\dagger$ Ephedrine sulfate $\left(33 \mathrm{mg}\right.$.) was injected intramuscularly at $65 \frac{1}{2}$ minutes after the injection of dihydroergocornine.

during a single experiment (Tables VI and VII, Figure 4). The marked fall in average renal blood flow for the first ten minute period of urine collection after injection of DHO, which included the time of sudden fall in arterial pressure, has been noted above. Hepatic-portal blood flow apparently fell similarly, but it was not measured at the time of greatest hypotensive response. However, in the second period, when renal blood flow was completely restored, hepatic-portal blood flow was greatly reduced; though it subsequently increased gradually, to regain the control level 32 minutes after administration of the drug.

\section{Renal Function}

Glomerular filtration rate usually paralleled the changes in renal plasma flow (Table VII, Figure 4). As a consequence there was little change in the filtration fraction. The most consistent change was in the urine flow which uniformly decreased and remained well below control values, even when the glomerular filtration rate and renal plasma flow had returned to pre-drug levels.

\section{Cardiac Output, Mean Arterial Pressure and Total Peripheral Resistance}

Changes in the cardiac output (catheterization method) in systemic arterial pressure (Hamilton method) and pulmonary arterial pressure were determined in two hypertensive and two normotensive subjects before and after the administration of DHO (Table VIII). In the two hypertensive subjects following the injection of 0.30 and 0.40 $\mathrm{mg}$. of DHO intravenously the mean arterial pressure fell 21 and 10 per cent, while the cardiac output increased 6 and 14 per cent, respectively. As a result the total peripheral resistance fell 25 and 20 per cent, respectively.

Whereas the hypertensive patients were studied only in the supine position, the two normotensive subjects were tested in both the supine and semi-erect positions (tilted upright to an angle of 


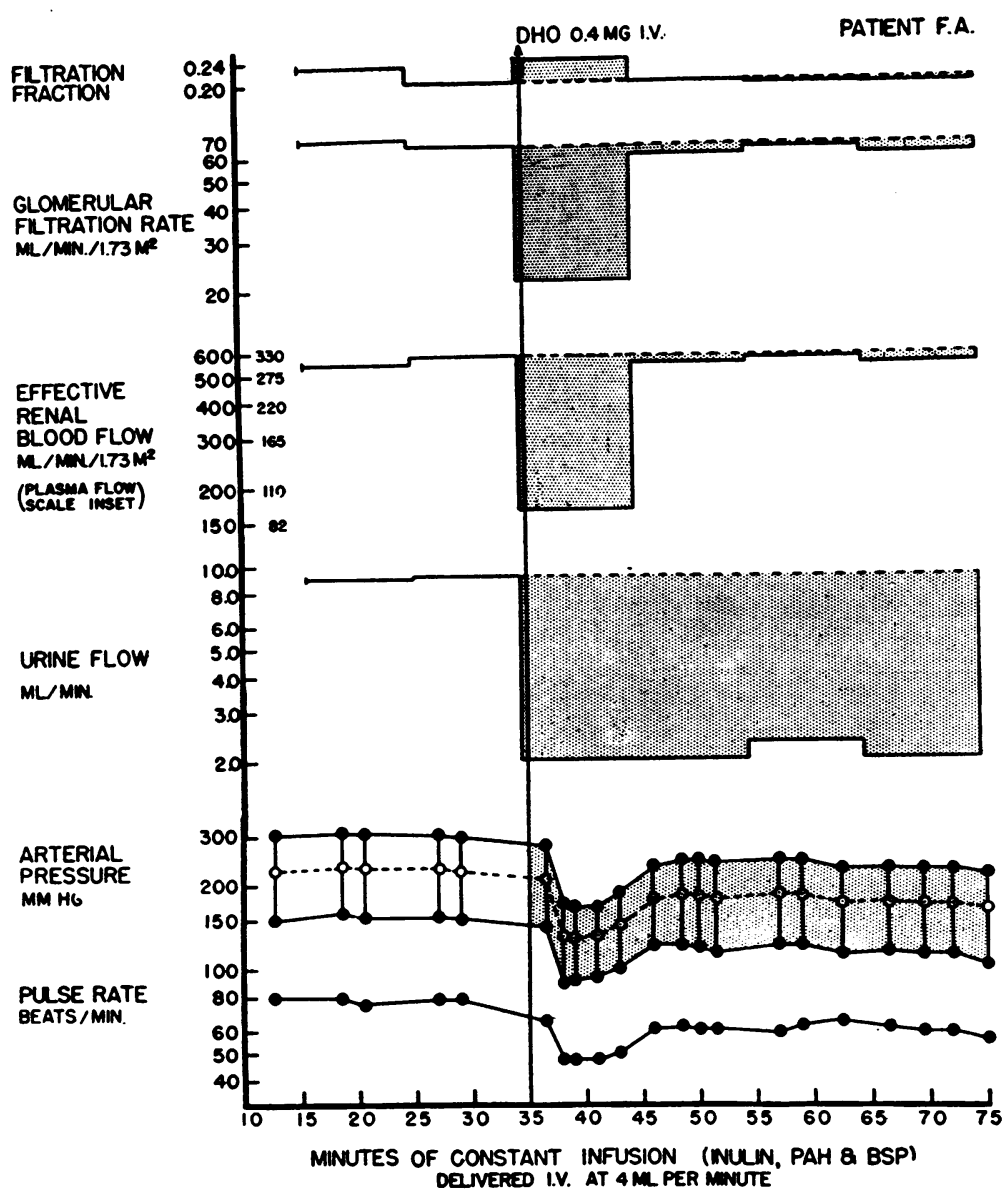

Fig. 4. Chart of Effective Renal Blood Flow, Glomerular Filtration Rate, Filtration Fraction, Urine Flow, Arterial Pressure and Pulse Rate Before and After the Intravenous Injection of 0.4 Mg. OF DHO in Patient F. A.

In the initial period there was a decrease in renal blood flow, glomerular filtration rate and urine flow associated with a reduction in arterial pressure and pulse rate. However, ten minutes after DHO, renal blood flow and glomerular filtration rate returned to control values despite continued significant reduction in urine flow, arterial pressure and pulse rate.

20 to $30^{\circ}$ ). In the two normotensive subjects, in the supine position, the changes following the drug were qualitatively similar to those observed in the hypertensive subjects. After $\mathrm{DHO}$, the mean arterial pressure decreased 12 and 7 per cent, respectively, the cardiac output increased 11 and 3 per cent, while the total peripheral resistance fell 21 and 10 per cent.

Pulmonary arterial pressure was not significantly changed after DHO in any of the subjects. In the semi-erect position one of the normotensive subjects tolerated the $30^{\circ}$ tilt for the five minute test period without discomfort. Whereas before the drug the mean arterial pressure rose during the tilt, after the drug it fell (postural hypotension). When the table was tilted to $30^{\circ}$ the cardiac output fell both before and after the drug, but more so after, and in both instances the total peripheral resistance rose. Thus, in this subject the postural hypotension appeared to be associated with a diminished cardiac output. The second normotensive subject (E. R., Table VIII) was not able to tolerate the $30^{\circ}$ tilted position after the drug and developed early signs of collapse in- 
TABLE VII

Effect of dihydroergocornine on renal plasma flow, glomerular filtration rate, filtration fraction and urine volume

\begin{tabular}{|c|c|c|c|c|c|c|c|c|c|c|c|c|c|c|}
\hline \multirow{3}{*}{$\begin{array}{l}\text { Patient and } \\
\text { diagnosis }\end{array}$} & \multirow{3}{*}{ Sex } & \multirow{3}{*}{ Age } & \multicolumn{6}{|c|}{ Control } & \multicolumn{6}{|c|}{ After dihydroergocornine } \\
\hline & & & \multirow{2}{*}{$\begin{array}{l}\text { Arterial } \\
\text { pressure }\end{array}$} & \multicolumn{2}{|c|}{ Plasma clearance } & \multirow{2}{*}{$\begin{array}{c}\text { Filtra- } \\
\text { tion } \\
\text { frac- } \\
\text { tion }\end{array}$} & \multirow{2}{*}{$\begin{array}{c}\text { Urine } \\
\text { volume }\end{array}$} & \multirow{2}{*}{ Dose } & \multirow{2}{*}{$\begin{array}{c}\text { Time after } \\
\text { drug ad- } \\
\text { ministra- } \\
\text { tion }\end{array}$} & \multirow{2}{*}{$\begin{array}{l}\text { Arterial } \\
\text { pressure }\end{array}$} & \multicolumn{2}{|c|}{ Plasma clearance } & \multirow{2}{*}{$\begin{array}{c}\text { Filtra- } \\
\text { tion } \\
\text { frac- } \\
\text { tion }\end{array}$} & \multirow{2}{*}{$\begin{array}{l}\text { Urine } \\
\text { volume }\end{array}$} \\
\hline & & & & Inulin & РAH & & & & & & Inulin & PAH & & \\
\hline$\underset{\text { Essential }}{\text { F. A. }}$ & $\mathbf{M}$ & 59 & $\mid$\begin{tabular}{c|} 
\\
$m m . H g$ \\
$308 / 156$ \\
$302 / 153$
\end{tabular} & $\begin{array}{c}\text { cc. per } \\
\text { min. } \\
\text { per } 1.73 \\
\text { sq.m. } \\
68.0 \\
64.5\end{array}$ & $\begin{array}{c}c c . \text { per } \\
\text { min. } \\
\text { per } 1.73 \\
\text { sq.m. } \\
299 \\
320\end{array}$ & $\begin{array}{c}\text { percenl } \\
22.7 \\
20.2\end{array}$ & \begin{tabular}{|}
$c c$. per \\
min. \\
8.55 \\
9.15
\end{tabular} & $\begin{array}{l}m g . \\
0.4\end{array}$ & $\begin{array}{c}\text { minutes } \\
3.5 \\
\\
12 \\
22.5 \\
32.5\end{array}$ & \begin{tabular}{|c|} 
\\
$m m . H g$ \\
$167 / 90$ \\
$235 / 120$ \\
$242 / 115$ \\
$235 / 112$
\end{tabular} & $\begin{array}{c}c c . \text { per } \\
\text { min. } \\
\text { per } 1.73 \\
\text { sq.m. } \\
21.8 \\
60.0 \\
62.5 \\
58.3\end{array}$ & $\begin{array}{c}c c . \text { per. } \\
\text { min. } \\
\text { per } 1.73 \\
\text { sq.m. } \\
90 \\
298 \\
314 \\
296\end{array}$ & \begin{tabular}{|c|} 
per cent \\
24.3 \\
20.1 \\
19.9 \\
19.7
\end{tabular} & $\begin{array}{l}c c . \text { per } \\
\text { min. } \\
2.0 \\
2.0 \\
2.3 \\
2.0\end{array}$ \\
\hline$\underset{\text { Essential }}{\text { R. D. }}$ & $\mathbf{M}$ & 49 & $\begin{array}{l}192 / 106 \\
194 / 106\end{array}$ & $\begin{array}{l}76.4 \\
86.1\end{array}$ & $\begin{array}{l}369 \\
344\end{array}$ & $\begin{array}{l}20.7 \\
23.7\end{array}$ & $\begin{array}{l}7.16 \\
6.38\end{array}$ & 0.37 & \begin{tabular}{l}
\multicolumn{1}{c}{4} \\
15 \\
23.5 \\
36.5 \\
51
\end{tabular} & $\begin{array}{l}188 / 102 \\
182 / 100 \\
176 / 96 \\
176 / 98 \\
172 / 100\end{array}$ & $\begin{array}{l}58.8 \\
54.2 \\
86.0 \\
76.2\end{array}$ & $\begin{array}{l}265 \\
256 \\
230 \\
347 \\
312\end{array}$ & $\begin{array}{l}22.2 \\
23.6 \\
24.8 \\
24.4\end{array}$ & $\begin{array}{l}3.81 \\
3.335 \\
1.04 \\
2.19 \\
2.645\end{array}$ \\
\hline$\underset{\substack{\text { Essential } \\
\text { hypertension }}}{\text { M. G. }}$ & $\mathbf{M}$ & 49 & $\begin{array}{l}220 / 122 \\
222 / 122\end{array}$ & $\begin{array}{l}130 \\
143\end{array}$ & $\begin{array}{l}510 \\
680\end{array}$ & $\begin{array}{l}25.5 \\
21.0\end{array}$ & $\begin{array}{l}9.9 \\
9.43\end{array}$ & $\begin{array}{c}0.25 \\
0.25 \\
\text { at six } \\
\text { minutes }\end{array}$ & $\begin{array}{r}4 \\
15 \\
17 \\
42\end{array}$ & $\begin{array}{l}220 / 118 \\
212 / 116 \\
200 / 116 \\
196 / 120\end{array}$ & $\begin{array}{l}97.5 \\
116.5 \\
108 \\
112.8\end{array}$ & $\begin{array}{l}518 \\
569 \\
418 \\
488\end{array}$ & $\begin{array}{l}18.8 \\
20.5 \\
25.8 \\
23.1\end{array}$ & $\begin{array}{l}7.8 \\
9.38 \\
3.99 \\
2.49\end{array}$ \\
\hline $\begin{array}{c}\text { W. W. } \\
\text { Essential } \\
\text { hypertension }\end{array}$ & $\mathbf{M}$ & 20 & $\begin{array}{l}142 / 96 \\
140 / 98\end{array}$ & $\begin{array}{l}95.2 \\
91.7\end{array}$ & $\begin{array}{l}605 \\
540\end{array}$ & $\begin{array}{l}16.2 \\
17.4\end{array}$ & $\begin{array}{l}1.045 \\
0.875\end{array}$ & \begin{tabular}{|c|}
0.25 \\
0.25 \\
at eight \\
minutes
\end{tabular} & $\begin{array}{l}1.5 \\
7 \\
16 \\
31\end{array}$ & $\begin{array}{l}144 / 96 \\
126 / 88 \\
138 / 92 \\
136 / 90\end{array}$ & $\begin{array}{r}102.5 \\
65.0 \\
86.1 \\
97.2\end{array}$ & $\begin{array}{l}492 \\
300 \\
453 \\
482\end{array}$ & $\begin{array}{l}20.3 \\
21.1 \\
18.5 \\
19.7\end{array}$ & $\begin{array}{l}0.69 \\
0.4 \\
0.7 \\
0.67\end{array}$ \\
\hline $\begin{array}{c}\text { K. M. } \\
\text { Essential } \\
\text { hypertension }\end{array}$ & $F$ & 52 & $178 / 88$ & 76.5 & 383 & 20.0 & 1.76 & 0.30 & $\begin{array}{r}3 \\
12 \\
42 \\
60\end{array}$ & $\begin{array}{l}170 / 88 \\
142 / 80 \\
135 / 80 \\
155 / 82\end{array}$ & $\begin{array}{r}103.5 \\
68.5 \\
42.0 \\
94.0\end{array}$ & $\begin{array}{l}392 \\
270 \\
212 \\
367\end{array}$ & $\begin{array}{l}26.4 \\
25.4 \\
19.8 \\
25.6\end{array}$ & $\begin{array}{l}2.2 \\
0.625 \\
0.42 \\
1.25\end{array}$ \\
\hline
\end{tabular}

TABLE VIII

Effect of DHO on blood pressure, pulmonary arterial pressure, cardiac output and total peripheral resistance

\begin{tabular}{|c|c|c|c|c|c|c|c|c|c|c|c|c|c|c|}
\hline \multirow[b]{2}{*}{$\begin{array}{l}\text { Patient and } \\
\text { diagnosis }\end{array}$} & \multirow[b]{2}{*}{ Sex } & \multirow[b]{2}{*}{ Age } & \multicolumn{6}{|c|}{ Control } & \multicolumn{6}{|c|}{ After DHO } \\
\hline & & & $\begin{array}{c}\text { Mean } \\
\text { arterial } \\
\text { pressure }\end{array}$ & $\underset{\text { rate }}{\text { Cardiac }}$ & $\begin{array}{l}\text { Pulmon- } \\
\text { ary ar- } \\
\text { terial } \\
\text { pressure }\end{array}$ & $\begin{array}{l}\text { Cardiac } \\
\text { output }\end{array}$ & $\begin{array}{l}\text { Total } \\
\text { periph- } \\
\text { eral re- } \\
\text { sistance }\end{array}$ & $\begin{array}{l}\text { Dose of } \\
\text { DHO }\end{array}$ & $\begin{array}{l}\text { Time } \\
\text { after } \\
\text { drug }\end{array}$ & $\begin{array}{c}\text { Mean } \\
\text { arterial } \\
\text { pressure }\end{array}$ & $\begin{array}{c}\text { Cardiac } \\
\text { rate }\end{array}$ & $\begin{array}{l}\text { Pulmon- } \\
\text { ary ar- } \\
\text { terial } \\
\text { pressure }\end{array}$ & $\begin{array}{l}\text { Cardiac } \\
\text { output }\end{array}$ & $\begin{array}{l}\text { Total } \\
\text { periph- } \\
\text { eral re- } \\
\text { sistance }\end{array}$ \\
\hline$\underset{\text { Essential }}{\text { J. H. }}$ & $\mathbf{M}$ & 40 & $\begin{array}{l}m m . H g \\
132 \\
132\end{array}$ & $\begin{array}{c}\text { per } \\
\text { minute } \\
83 \\
80\end{array}$ & $\begin{array}{l}m m . H g \\
31 / 13 \\
31 / 6\end{array}$ & $\begin{array}{c}\text { liters } \\
\text { per } \\
\text { minute } \\
6.65 \\
6.35\end{array}$ & $\begin{array}{c}\text { dynes cm. } \\
5-\mathrm{sec} . \\
1590 \\
1670\end{array}$ & $\begin{array}{l}m g . \\
I . V . \\
0.30\end{array}$ & $\begin{array}{c}\text { minules } \\
9 \\
23\end{array}$ & $\begin{array}{l}m m . H g \\
104 \\
105\end{array}$ & $\begin{array}{c}\text { per } \\
\text { minute } \\
78 \\
76\end{array}$ & $\begin{array}{l}m m . H g \\
33 / 15 \\
28 / 6\end{array}$ & 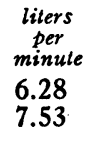 & $\begin{array}{c}\text { dynes cm. } \\
5-\mathrm{sec} . \\
1320 \\
1120\end{array}$ \\
\hline $\begin{array}{c}\text { F. S. } \\
\text { Essential } \\
\text { hypertension }\end{array}$ & $\mathbf{M}$ & 58 & $\begin{array}{l}130 \\
133\end{array}$ & $\begin{array}{l}93 \\
95\end{array}$ & $\begin{array}{l}31 / 8 \\
31 / 12\end{array}$ & $\begin{array}{l}7.01 \\
6.61\end{array}$ & $\begin{array}{l}1480 \\
1610\end{array}$ & 0.40 & $\begin{array}{r}4 \\
16\end{array}$ & $\begin{array}{l}124 \\
114\end{array}$ & $\begin{array}{l}83 \\
83\end{array}$ & $\begin{array}{l}33 / 14 \\
28 / 13\end{array}$ & $\begin{array}{l}8.59 \\
6.94\end{array}$ & $\begin{array}{l}1160 \\
1320\end{array}$ \\
\hline $\begin{array}{l}\text { F. M. } \\
\text { Normotensive } \\
\text { primary syph- } \\
\text { ilis treated }\end{array}$ & $\mathbf{M}$ & 21 & $\begin{array}{l}104.8 \\
108.6\end{array}$ & $\begin{array}{l}117 \\
117\end{array}$ & $\begin{array}{l}17 / 5 \\
26 / 10\end{array}$ & $\begin{array}{l}7.36 \\
7.08 *\end{array}$ & $\begin{array}{l}1150 \\
1230\end{array}$ & 0.25 & $\begin{array}{r}5 \\
15\end{array}$ & $\begin{array}{l}98.0 \\
82.8\end{array}$ & $\begin{array}{l}106 \\
111\end{array}$ & $\begin{array}{l}17 / 9 \\
27 / 10\end{array}$ & $\begin{array}{l}7.60 \\
6.12^{*}\end{array}$ & $\begin{array}{l}1030 \\
1070\end{array}$ \\
\hline $\begin{array}{l}\text { E. R. } \\
\text { Normotensive } \\
\text { primary syph- } \\
\text { ilis treated }\end{array}$ & $\mathbf{M}$ & 21 & $\begin{array}{l}104.3 \\
100.2\end{array}$ & $\begin{array}{l}71 \\
95\end{array}$ & $\begin{array}{l}30 / 11 \\
38 / 21\end{array}$ & $\begin{array}{l}5.90 \\
6.13^{*}\end{array}$ & $\begin{array}{l}1430 \\
1310\end{array}$ & 0.25 & $\begin{array}{r}9 \\
27\end{array}$ & $\begin{array}{l}90.7 \\
87.8\end{array}$ & $\begin{array}{l}73 \\
88\end{array}$ & $\begin{array}{l}29 / 13 \\
28 / 11\end{array}$ & $\begin{array}{l}6.55 \\
9.20 \dagger\end{array}$ & $\begin{array}{r}1105 \\
765\end{array}$ \\
\hline
\end{tabular}

* Patient tilted upright $30^{\circ}$.

† Patient tilted upright $20^{\circ}$ (Recovering from collapse which had occurred at $30^{\circ}$ upright). 
cluding weakness and sweating. He was tilted back to an angle of $20^{\circ}$, a position he could tolerate, and the determinations were then carried out. The mean arterial pressure fell slightly from 91 $\mathrm{mm}$. supine to $88 \mathrm{~mm}$. $\mathrm{Hg}$ during the $20^{\circ}$ tilt, but the cardiac output increased markedly from 6.55 liters at $0^{\circ}$ to 9.2 liters per minute at $20^{\circ}$. Since the patient was recovering from incipient collapse during this period the increase in cardiac output may have been associated with compensatory reactions occurring with the recovery.

\section{Other Effects}

\section{Heart Rate}

A decrease in heart rate following $\mathrm{DHO}$ was noted in the present cases as well as in subjects studied previously $(10,11,19)$ (Table VIII, Figure 4). In addition, the reduction of arterial pressure in the erect position after DHO, unlike that after lumbodorsal splanchnicectomy or the administration of tetraethylammonium, was not accompanied by tachycardia (Table II).

The bradycardia was only partially abolished by the administration of doses of atropine sulfate which ordinarily produce significant tachycardia in man ( 0.75 to $1.0 \mathrm{mg}$. intravenously). In four patients in whom atropine was injected following DHO the acceleration of heart rate varied from 6 to 19 beats per minute. In no instance was the administration of atropine followed by definite tachycardia.

\section{The Response to Venous Congestion of the Extremities}

Investigations in this laboratory (20) have disclosed that drugs which cause postural hypotension may cause similar hypotension and collapse in patients who are supine when the venous return from the extremities is compromised by inflating at slightly below diastolic pressure pneumatic cuffs placed proximally about the thighs and one upper arm.

Prior to the drug three hypertensive subjects tolerated such congestion of the extremities for five minutes with no significant alterations in arterial pressure. However, after $0.5 \mathrm{mg}$. of $\mathrm{DHO}$ intravenously two of the three subjects developed hypotension, bradycardia and collapse between four and five minutes after the application of sim- ilar congesting pressures to the same regions. The significance of these results with respect to the mechanism of the collapse and the effects of other drugs will be reported in another communication (20).

\section{Effect of DHO and DHK on the Response to the Intravenous Administration of Epinephrine}

The dihydrogenated alkaloids of ergot are reported to inhibit the pressor response to epinephrine in the anaesthetized experimental animal (8). Similarly in unanaesthetized animals (8) and man (11), DHK may block the hyperglycemic response to epinephrine.

The adrenolytic properties of DHO and DHK on cardiovascular functions were investigated by the use of gradually increasing intravenous doses of epinephrine instantaneously injected. As noted previously in this laboratory (21), the characteristic response to minimal ( 0.5 to $1 \mu \mathrm{g}$.) doses of epinephrine thus administered is mainly depressor and is accompanied by cardiac acceleration and a slight increase in the antecubital venous pressure. After slightly larger doses of epinephrine the depressor response, while still present, is followed by a later pressor phase which increases in magnitude and duration with the dose of epinephrine.

Both DHO and DHK inhibited the depressor phase when single doses of 0.5 to $1.0 \mu \mathrm{g}$. of epinephrine were administered intravenously (Table IX). The inhibition was least evident in the response of the arterial pressure, more apparent in the heart rate, and most evident in the response of the venous pressure. However, with increasing doses of epinephrine $(2 \mu \mathrm{g}$.) inhibition of the depressor phase was not consistent. Further, in the pressor phase of the epinephrine response the rise in arterial pressure was not significantly altered by either DHO or DHK, although the tachycardia and rise in venous pressure were slightly inhibited. Thus, in contrast with the results obtained in experimental animals (8), the dihydrogenated alkaloids of ergot in the doses used appeared to have only slight adrenolytic activity with respect to these cardiovascular functions in man. It is of interest, however, that in a patient with pheochromocytoma both a continued hypertension as well as a marked pressor reaction 
TABLE IX

Effect of DHK or DHO on depressor and pressor phases following intravenous administration of small doses of epinephrine

\begin{tabular}{|c|c|c|c|c|c|c|}
\hline \multirow{2}{*}{$\begin{array}{l}\text { Patient and dose } \\
\text { of epinephrine }\end{array}$} & \multicolumn{3}{|c|}{ Control } & \multicolumn{3}{|c|}{ After DHK or DHO } \\
\hline & $\begin{array}{c}\text { Mean arterial } \\
\text { pressure*** } \\
\text { per cent change }\end{array}$ & $\begin{array}{c}\text { Heart rate } \\
\text { per cent } \\
\text { change }\end{array}$ & $\begin{array}{l}\text { Venous pressuret } \\
\text { per cent change }\end{array}$ & $\begin{array}{c}\text { Mean arterial } \\
\text { pressure** } \\
\text { per cent change }\end{array}$ & $\begin{array}{l}\text { Heart rate } \\
\text { per cent } \\
\text { change }\end{array}$ & $\begin{array}{l}\text { Venous pressure } \\
\text { per cent change }\end{array}$ \\
\hline \multicolumn{7}{|l|}{ Depressor phase } \\
\hline $\begin{array}{c}\text { C. P. } \\
\text { (1.5 mg. DHK I.V.) } \\
2.0 \mu \mathrm{\mu g} . \\
2.0 \mu \mathrm{gg} . \\
4.0 \mu \mathrm{g} . \\
\end{array}$ & $\begin{array}{l}-22 \\
-12 \\
-10 \\
\end{array}$ & $\begin{array}{r}+24 \\
+\quad 9 \\
+29 \\
\end{array}$ & & $\begin{array}{l}-18 \\
-22 \\
-11 \\
\end{array}$ & $\begin{array}{r}+5 \\
+10 \\
+27\end{array}$ & \\
\hline $\begin{array}{c}\text { F. G. } \\
\text { (1.5 mg. DHK I.V.) } \\
0.5 \mu \mathrm{g} . \\
1.0 \mu \mathrm{g} . \\
2.0 \mu \mathrm{g} . \\
5.0 \mu \mathrm{g} . \\
\mathbf{8 . 0} \mu \mathrm{g} . \\
\end{array}$ & $\begin{array}{l}-11 \\
-16 \\
-23 \\
-16 \\
-14 \\
\end{array}$ & $\begin{array}{l}+16 \\
+22 \\
+30 \\
+41 \\
+29 \\
\end{array}$ & $\begin{array}{l}+5 \\
+5 \\
+12 \\
+18 \\
+16 \\
\end{array}$ & $\begin{array}{r}0 \\
-14 \\
-22 \\
-18 \\
-17\end{array}$ & $\begin{array}{r}0 \\
+5 \\
+22 \\
+38 \\
+36 \\
\end{array}$ & $\begin{array}{r}0 \\
0 \\
0 \\
+11 \\
+10 \\
\end{array}$ \\
\hline $\begin{array}{c}\text { M. H. } \\
\text { (0.3 mg. DHO I.V.) } \\
0.5 \mu \mathrm{g} . \\
1.0 \mu \mathrm{g} . \\
2.0 \mu \mathrm{g} . \\
4.0 \mu \mathrm{g} . \\
5.0 \mu \mathrm{g} . \\
10.0 \mu \mathrm{g} . \\
\end{array}$ & $\begin{array}{l}-14 \\
-12 \\
-11 \\
-16 \\
-15 \\
-9\end{array}$ & $\begin{array}{r}0 \\
+10 \\
+20 \\
+33 \\
+29 \\
+40\end{array}$ & & $\begin{array}{l}-2 \\
=3 \\
=10 \\
=11 \\
=6 \\
-9\end{array}$ & $\begin{array}{r}0 \\
+7 \\
+13 \\
+36 \\
+20 \\
+40\end{array}$ & \\
\hline \multicolumn{7}{|l|}{ Pressor phase } \\
\hline $\begin{array}{c}\text { C. P. } \\
\text { (1.5 mg. DHK I.V.) } \\
2.0 \mu g . \\
2.0 \mu g . \\
4.0 \mu g .\end{array}$ & $\begin{array}{r}+10 \\
+4 \\
+10\end{array}$ & $\begin{array}{r}+17 \\
+5 \\
+11\end{array}$ & & $\begin{array}{r}+5 \\
+3 \\
+12\end{array}$ & $\begin{array}{r}0 \\
0 \\
+5\end{array}$ & \\
\hline $\begin{array}{c}\text { F. G. } \\
(1.5 \mathrm{mg} \text {. DHK I.V.) } \\
0.5 \mu \mathrm{g} . \\
1.0 \mu \mathrm{g} . \\
2.0 \mu \mathrm{g} . \\
5.0 \mu \mathrm{g} . \\
\mathbf{8 . 0} \mu \mathrm{g} .\end{array}$ & $\begin{array}{r}0 \\
0 \\
0 \\
+5 \\
+\quad 4 \\
\end{array}$ & $\begin{array}{r}0 \\
0 \\
+7 \\
+14 \\
+10 \\
\end{array}$ & $\begin{array}{r}0 \\
0 \\
+6 \\
+12 \\
+6\end{array}$ & $\begin{array}{r}0 \\
0 \\
0 \\
+7 \\
0\end{array}$ & $\begin{array}{r}0 \\
0 \\
+7 \\
+3 \\
0\end{array}$ & $\begin{array}{r}0 \\
0 \\
0 \\
+5 \\
+5 \\
\end{array}$ \\
\hline $\begin{array}{c}\text { M. H. } \\
\text { (0.3 mg. DHO I.V.) } \\
2.0 \mu g . \\
4.0 \mu g . \\
5.0 \mu g . \\
10.0 \mu g .\end{array}$ & $\begin{array}{r}0 \\
+6 \\
+3 \\
+12\end{array}$ & $\begin{array}{r}0 \\
0 \\
+5 \\
+5\end{array}$ & & $\begin{array}{l}+13 \\
+13 \\
+9 \\
+17\end{array}$ & $\begin{array}{r}0 \\
0 \\
0 \\
+5\end{array}$ & \\
\hline
\end{tabular}

* One-half the sum of the systolic plus the diastolic pressure $\left(S+\frac{D}{2}\right)$. Hamilton manometer recordings from the brachial artery.

$\dagger$ Hamilton manometer recordings from the antecubital veins.

to the histamine test were promptly relieved by intravenously injected DHK (22).

Since it has been suggested that the pressor and cardio-accelerator responses to emotional stimuli may be due at least in part to epinephrine discharge (23) it was considered of interest to de- termine the effect of the emotional stimulus of a problem in mental arithmetic on the arterial pressure before and after DHO. Of three patients tested the pressor response was reduced in two after as compared with before DHO, while the accelerator reaction was reduced in all. These re- 
sults must be interpreted with caution, however, since such stimuli tend to lose emotional impact on repetition.

\section{"Vascular Distensibility" in the Extremities}

At intervals during the studies of limb blood flow the "vascular distensibility" (increase in volume during graded venous congestion) in the forearm and leg was determined in 14 subjects according to the method of Litter and Wilkins (24). In almost all cases there was a significant decrease in the vascular distensibility, which occurred more consistently than any of the changes in limb blood flow, but did not correlate with either the fluctuations in arterial pressure or the blood flow. The significance of these findings will be discussed elsewhere (24).

Venous pressure in the antecubital vein, recorded in four subjects with a Hamilton manometer, rose 1 to $4 \mathrm{~mm}$. of mercury, after DHO. The marked increase in peripheral venous pressure during the Valsalva maneuver was also considerably greater after as compared with before DHO. In addition, arterial pulsations became more prominent in the antecubital venous recordings after the drug (Figure 2).

\section{DISCUSSION}

This investigation supplied additional evidence confirming the conclusions of Bluntschli and Goetz (10) that DHO has sympatholytic effects in man. It disclosed that DHO not only inhibits vasoconstriction in the extremities, but also depresses vasopressor responses mediated over sympathetic pathways.

The bradycardia which frequently follows the injection of the dihydrogenated ergot alkaloids also appeared to be due in part to inhibition of the sympathetic cardio-accelerator mechanism, since after DHO doses of atropine sufficient to inhibit vagal influence on cardiac rate failed to produce significant tachycardia. In contrast to their apparent sympatholytic effects, the dihydrogenated alkaloids in the doses used had only slight adrenolytic properties so far as the immediate cardiovascular reactions to injected epinephrine were concerned. Such evidence suggests that the circulatory changes observed in the present studies in man may have been due to the central action rather than the peripheral sympathetic-blocking effects of these drugs $(8,9)$.

The fall in arterial pressure following DHO, except in the semi-erect position, was associated with maintenance of cardiac output, and, hence, with a decrease in total peripheral resistance. The maintenance or slight increase in cardiac output may have been influenced by any one or a combination of the following factors: 1) the maintenance of right cardiac filling pressure as evidenced by the rise in peripheral venous pressure and unchanged pulmonary arterial pressure, 2) the cardiac slowing which permitted more effective diastolic filling, and 3) the diminished peripheral resistance. A similar hemodynamic response was observed after veratrum viride (13), the action of which also involves the vascular centers in the nervous system. Such a response is in marked contrast to that caused by certain peripherally acting vasodilators such as sodium nitrite after which cardiac output falls in association with compensatory tachycardia and a decrease in venous and pulmonary arterial pressure (25).

Although total peripheral resistance decreased uniformly after DHO the pattern of blood flow in discrete peripheral areas exhibited marked fluctuations. In the renal area the blood flow decreased early, but later increased to or toward control values. Blood flow in the muscles usually increased and in the splanchnic area usually decreased, but these changes were inconstant. Thus, peripheral resistance in different regions might increase, decrease, or vary from one direction to the other during a reduction in blood pressure. In this regard it is of interest that Hafkenschiel and his coworkers (26) found that cerebral vascular resistance was reduced after $\mathrm{DHO}$ in hypertensive, but not in normotensive subjects.

This lack of uniform response may indicate that the hypotensive effects of the drug had called forth counteracting mechanisms; or that the drug itself had multiple effects, including opposing actions on the blood vessels. The constrictor action on arteriolar muscle that is exhibited by the naturally occurring ergot alkaloids is said to be minimal with the dihydrogenated derivatives in animals (8), and in the digits of man (10). However, it is possible that in the muscular and hepaticportal areas of man the direct vasoconstrictor 
effect may become active and at times may be occasionally dominant.

Either hypothesis, 1) activation of compensatory vasoconstrictor mechanisms, or 2) multiple opposing actions of the drug, could explain not only the variable changes in blood flow in the splanchnic bed and muscles, but also the apparent failure of DHO to bring about a hypotensive response in certain patients despite evidence of inhibition of sympathetic reflex vasoconstriction (11). The possibility that the hypotensive effect of the drug may be due to some property other than a sympatholytic action also cannot be excluded.

The only peripheral areas studied which manifested a consistent pattern of vasodilatation were the hands and feet when the subjects were examined in a warm room. A decrease in peripheral resistance was manifested by a rise in skin temperature, an increase in pulse volume, and by the presence of arterial pulsations in the venous pressure recordings taken from the antecubital vein. The rise in antecubital venous pressure after $\mathrm{DHO}$ in all probability was secondary to the increased arterial inflow, resulting from the local arteriolar vasodilatation without a correspondingly increased venous outflow. The increased pulsation in the veins could have been due partly to transmission from neighboring arteries across intervening tissues. However, this seems unlikely since 1) the pulse in the larger arteries, such as the brachial and radial, became less, rather than more bounding after the drug, 2) the increased pulsation also was observed in superficial veins remote from larger arteries, and 3) since there was obvious evidence of peripheral arteriolar vasodilatation, particularly in the digits, transmission of the pulse waves through the dilated vascular beds to the veins seems a more likely explanation for their presence in the venous tracings.

There were many points of similarity between DHO and tetraethylammonium. Both drugs inhibited sympathetic vasoconstrictor reflexes (27), raised skin temperature in the digits (28), produced an initial decrease in renal clearances followed by a return to control values (29), and as a rule increased limb blood flows $(28,30)$. The chief points of difference were that after tetraethylammonium the cardiac output either decreased (31) or remained unchanged (28), the heart rate increased (32) and the pulmonary arterial pressure decreased (31). The reason for these differences is not clear unless they were related to the different sites of action of the two drugs $(8,33)$.

It was of interest also to compare the effects of $\mathrm{DHO}$ with those of veratrum viride, since the hypotensive action of both drugs is believed to be mediated through the central nervous system $(9,34)$. The two drugs were similar, in that both could decrease arterial pressure and heart rate without depressing cardiac output, they both produced oliguria, and brought about a decrease in renal blood flow during the early, falling phase of the hypotensive response. They were dissimilar in that following suitable doses of veratrum viride significant hypotension occurred almost without exception, the changes in peripheral resistance were uniform in all the vascular areas studied, and the homeostatic vasoconstrictor reflexes remained intact. Atropine abolished the bradycardia induced by veratrum, but not that which followed DHO, while "vascular distensibility," in the extremities, which increased following veratrum, usually decreased after DHO.

Clinically these studies suggest that sympatholytic agents have certain fundamental limitations in the treatment of essential hypertension. First, as has been observed with other agents that inhibit sympathetic vasoconstrictor reflexes $(32,35,36)$, not all patients had a significant reduction in arterial pressure following the administration of DHO. Thus, the therapeutic use of this agent, as of other sympatholytic drugs, would seem to be limited to selected patients. Second, its apparent blockade or inhibition of reflex vasoconstrictor mechanism so interfered with homeostasis that at times vascular collapse seemed imminent or actually occurred. Finally, after it had been given, the changes in peripheral resistance in different vascular beds were so varied and unpredictable as to suggest that certain factors opposing a uniform vasodilatation were active.

\section{SUMMARY AND CONCLUSIONS}

Dihydroergocornine (DHO) administered intravenously in man produced the following hemodynamic effects : 
1. Vasopressor responses to blood-pressure-lowering procedures (Valsalva maneuver, upright tilting), and to the immersion of a hand in iced water (cold test) were inhibited or abolished. Skin temperature in the digits exhibited significant increases in a warm, but not in a cool environment. Digital pulse volumes increased, and reflex vasoconstrictor responses to "noxius" stimuli usually decreased.

2. Blood flow through the forearm and leg frequently increased as the arterial pressure fell, but it sometimes decreased or remained unchanged.

3. Blood flow through the hepatic-portal circuit also varied in different patients, occasionally remaining at control levels early in the hypotensive response, but usually becoming reduced proportionately more than the arterial pressure. The variability of the responses in blood flow in the limbs and in the hepatic-portal region suggests that the drug may have multiple and opposing effects, or that after it has been given, certain counteracting vasoconstrictor mechanisms may become activated.

4. Renal blood flow decreased initially, but in three of five patients it later returned to control levels. Glomerular filtration rate paralleled renal blood flow. Hence, there was little change in the filtration fraction. Oliguria occurred and persisted even when renal plasma flow and glomerular filtration rate returned to control values. Therefore, the oliguria appeared to be secondary to increased tubular reabsorption of water.

5. The fall in arterial pressure in the supine position was accompanied by no change or a slight increase in cardiac output. Total peripheral resistance, therefore, was reduced. The bradycardia accompanying the hypotensive response was not abolished by atropine.

6. Venous congestion by cuffs high on the extremities could precipitate collapse in supine patients who had received DHO.

7. "Vascular distensibility" in the limbs usually decreased, while venous pressure in the arm rose. Arterial pulsations became more prominent in the venous pressure recordings taken from the antecubital vein.

8. The alkaloids, dihydroergocornine and dihydroergokryptine, opposed only slightly the effects of epinephrine on the arterial pressure and heart rate of man.

\section{BIBLIOGRAPHY}

1. Dale, H. H., On some physiological actions of ergot. J. Physiol., 1906, 34, 163.

2. Stoll, A., Zur Kenntnis der Mutterkornalkaloide. Verh. d. Schweiz. Naturforsch. Ges., 1920, 101, 190.

3. Kharasch, M. S., King, H., Stoll, A., and Thompson, M. R., New ergot alkaloid. Science, 1936, 83, 206.

4. Stoll, A., and Hofmann, A., Die Alkaloide der Ergotoxingruppe: Ergocristin, Ergokryptin and Ergocornine. Helvet. chim. acta, 1943, 26, 1570.

5. Jacobs, W. A., and Craig, L. C., The position of the carboxyl group in the lysergic acid. J. Am. Chem. Soc., 1938, 60, 1701.

6. Jacobs, W. A., and Craig, L. C., The ergot alkaloids : lysergic acid. J. Biol. Chem., 1935, 111, 455.

7. Stoll, A., and Hofmann, A., Die dihydroderivate der Natürlichen Linksdrehenden Mutterkornalkaloide. Helvet. chim. acta, 1943, 26, 2070.

8. Rothlin, E., The pharmacology of the natural and dihydrogenated alkaloids of ergot. Bull. schweiz. Akad. d. med. Wissensch., 1947, 2, 249.

9. Bluntschli, H. J., Uber die Wirkung Eines ErgotDerivates (Dihydroergocornine) auf Blutdruck, Respiration und Electrokardiogram der Katze Nach Querschnittsdurchtrennung des Rückenmarks im Bereich der Thoracal-Segmente. Helvet. physiol. acta, 1948, 6, 50.

10. Bluntschli, H. J., and Goetz, C. B., The effect of ergot derivatives on the circulation in man with special reference to two new hydrogenated compounds (dihydroergocornine and dihydroergotamine). Am. Heart J., 1948, 35, 873.

11. Freis, E. D., Stanton, J. R., and Wilkins, R. W., The effects of certain dihydrogenated alkaloids of ergot in hypertensive patients. Am. J. M. S., 1948, 216, 163.

12. Bluntschli, H. J., and Goetz, R. H., The effect of a new sympatholytic drug (dihydroergocornine) on the blood pressure with special reference to hypertension. South African M. J., 1947, 21, 382.

13. Freis, E. D., Stanton, J. R., Culbertson, J. W., Litter, J., Halperin, M. H., Burnett, C. H., and Wilkins, R. W., The hemodynamic effect of hypotensive drugs in man. I. Veratrum viride. J. Clin. Invest., 1949, 28, 353.

14. Wilkins, R. W., and Culbertson, J. W., The effects of surgical sympathectomy upon certain vasopressor responses in hypertensive patients. $\mathrm{Tr}$. A. Am. Physicians, 1947, 60, 195.

15. Hecht, H. H., and Anderson, R. B., The influence of dibenamine ( $\mathrm{N}, \mathrm{N}$-dibenzyl- $\beta$-chloroethyl-amine) on certain functions of the sympathetic nervous system in man. Am. J. Med., 1947, 3, 3.

16. Reiser, M. F., and Ferris, E. B., Jr., The nature of the cold pressor test and its significance in relation to neurogenic and humoral mechanisms in hypertension. J. Clin. Invest., 1948, 27, 156. 
17. Russek, H. I., Southworth, J. L., and Zohman, B. L., Continuous caudal anaesthesia as $a$ test in the selection of hypertensive patients for sympathectomy. J. A. M. A., 1945, 128, 1225.

18. Page, I. H., Taylor, R. D., Corcoran, A. C., and Mueller, L., Correlation of clinical types with renal function in arterial hypertension. II. Effect of spinal anaesthesia. J. A. M. A., 1944, 124, 736.

19. Moister, F. C., Stanton, J. R., and Freis, E. D., Observations on the development of tolerance during prolonged administration of dihydroergocornine. J. Pharm. \& Exper. Therap., 1949, 96, 21.

20. Freis, E. D., Stanton, J. R., and Wilkins, R. W., In preparation.

21. Culbertson, J. W., Judson, W. E., Tinsley, C. M., Litter, J., and Wilkins, R. W., The comparative effects of small intravenous doses of epinephrine upon arterial pressure and pulse rate in normotensive subjects and in hypertensive patients before and after thoracolumbar sympathectomy. To be published.

22. Wilkins, R. W., and Greer, W. E. R., Unpublished data.

23. Cannon, W. B., Bodily Changes in Pain, Hunger, Fear and Rage. An account of recent researches into the function of emotional excitement. D. Appleton \& Co., New York and London, 1929, Ed. 2.

24. Litter, J., and Wilkins, R. W., "Vascular distensibility" in the forearm and calf of man. I. Plethysmographic measurement of vascular distention during venous congestion. In preparation.

25. Freis, E. D., Stanton, J. R., Litter, J., Culbertson, J. W., Halperin, M. H., Moister, F. C., and Wilkins, R. W., The hemodynamic effects of hypotensive agents in man. Am. J. Med., 1949, 7, 414.

26. Hafkenschiel, J. H., Crumpton, C. W., Mayer, J. H., and Jeffers, W. A., The effects of dihydroergocornine on the cerebral circulation of hypertensive and normotensive subjects. Presented at the Twentysecond Scientific Session of the American Heart Association, Atlantic City, New Jersey, June 3, 1949.
27. Wilkins, R. W., Stanton, J. R., and Freis, E. D. Unpublished data.

28. Hoobler, S. W., Neligh, R. B., Moe, G. K., Malton S. D., Cohen, S., Ballantine, H. T., Jr., and Lyons, R. H., Extent of vasodilatation induced in different vascular beds after systemic autonomic blockade with tetraethylammonium. Am. J. Med., 1947, 3, 125.

29. Hoobler, S. W., Moe, G. K., Rennick, B. R., Neligh, R. B., and Lyons, R. H., The effect of autonomic blockade with tetraethylammonium on the renal circulation in dogs and in normal and hypertensive patients. Univ. Hosp. Bull., Ann Arbor., 1947, 13, 9.

30. Kowalski, H. J., Hoobler, S. W., Malton, S. D., Pain, W. G., Lyons, R. H., Moe, G. K., and Manning, J. T., Studies on vasomotor tone in hypertension. Effect of tetraethylammonium on blood flow in the extremities of normal and hypertensive subjects. Am. J. Med., 1948, 4, 780.

31. Frisk, A. R., Hammarström, S., Lagerlöf, H., Werkö, L., Björkenheim, G., Halmgren, A., and Larsson, Y., Effects of tetraethylammonium in arterial hypertension. Am. J. Med., 1948, 5, 807.

32. Lyons, R. H., Hoobler, S. W., Neligh, R. B., Moe, G. K., and Peet, M. M., Experiences with tetraethylammonium chloride in hypertension. J. A. M. A., 1948, 136, 608.

33. Acheson, G. H., and Moe, G. K., The action of tetraethylammonium ion on the mammalian circulation. J. Pharmacol. \& Exper. Therap., 1946, 87, 220.

34. Krayer, O., and Acheson, G. H., The pharmacology of the veratrum alkaloids. Physiol. Rev., 1946, 26, 383.

35. Grimson, K. S., Reardon, M. J., Margori, F. A., and Hendrix, J. P., The effects of priscol (2-benzyl-4, 5-imidazoline $\mathrm{HC1}$ ) on peripheral vascular diseases, hypertension and circulation in patients. Ann. Surg., 1948, 127, 968.

36. Freis, E. D., and Wilkins, R. W., Effect of pentaquine in patients with essential hypertension. Proc. Soc. Exper. Biol. \& Med., 1947, 64, 455. 